Original Article

\title{
Honey as a bioindicator of environmental organochlorine insecticides contamination
}

\author{
Mel como bioindicador de contaminação ambiental de inseticidas organoclorados
}

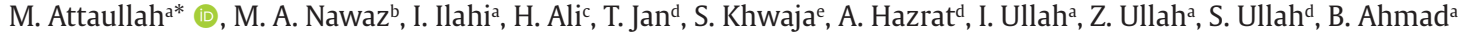 \\ and R. Ullah ${ }^{\mathrm{f}}$ \\ aUniversity of Malakand, Department of Zoology, Chakdara, Dir Lower, Pakistan \\ bShaheed Benazir Bhutto University, Department of Biotechnology, Dir Upper, Pakistan \\ cUniversity of Malakand, Department of Chemistry, Chakdara, Dir Lower, Pakistan \\ dUniversity of Malakand, Department of Botany, Chakdara, Dir Lower, Pakistan \\ eFederal Urdu University of Arts, Science and Technology, Department of Zoology, Karachi, Pakistan \\ fShaheed Benazir Bhutto University, Department of Zoology, Dir Upper, Pakistan
}

\begin{abstract}
Honey is a suitable matrix for the evaluation of environmental contaminants including organochlorine insecticides. The present study was conducted to evaluate residues of fifteen organochlorine insecticides in honey samples of unifloral and multifloral origins from Dir, Pakistan. Honey samples ( $5 \mathrm{~g}$ each) were extracted with GC grade organic solvents and then subjected to Rotary Evaporator till dryness. The extracts were then mixed with n-Hexane $(5 \mathrm{ml})$ and purified through Column Chromatography. Purified extracts $(1 \mu \mathrm{l}$ each) were processed through Gas Chromatograph coupled with Electron Capture Detector (GC-ECD) for identification and quantification of the insecticides. Of the 15 insecticides tested, $46.7 \%$ were detected while $53.3 \%$ were not detected in the honey samples. Heptachlor was the most prevalent insecticide with a mean level of $0.0018 \mathrm{mg} / \mathrm{kg}$ detected in $80 \%$ of the samples followed by $\beta-\mathrm{HCH}$ with a mean level of $0.0016 \mathrm{mg} / \mathrm{kg}$ detected in $71.4 \%$ of the honey samples. Honey samples from Acacia modesta Wall. were $100 \%$ positive for Heptachlor with a mean level of $0.0048 \mathrm{mg} / \mathrm{kg}$ followed by $\beta$-HCH with a mean level of $0.003 \mathrm{mg} / \mathrm{kg}$ and frequency of $83.3 \%$. Minimum levels of the tested insecticides were detected in the unifloral honey from Ziziphus jujuba Mill. Methoxychlor, Endosulfan, Endrin and metabolites of DDT were not detected in the studied honey samples. Some of the tested insecticides are banned in Pakistan but are still detected in honey samples indicating their use in the study area. The detected levels of all insecticides were below the Maximum Residue Levels (MRLs) and safe for consumers. However, the levels detected can cause mortality in insect fauna. The use of banned insecticides is one of the main factors responsible for the declining populations of important insect pollinators including honeybees.
\end{abstract}

Keywords: insecticides, honeybees, insect pollinators, public health, GC-ECD.

\begin{abstract}
Resumo
O mel é uma matriz adequada para a avaliação de contaminantes ambientais, incluindo inseticidas organoclorados. O presente estudo foi conduzido para avaliar resíduos de 15 inseticidas organoclorados em amostras de mel de origem unifloral e multifloral de Dir, Paquistão. Amostras de mel ( $5 \mathrm{~g}$ cada) foram extraídas com solventes orgânicos de grau GC e, em seguida, submetidas ao evaporador rotativo até a secura. Os extratos foram então misturados com n-hexano ( $5 \mathrm{ml}$ ) e purificados por cromatografia em coluna. Os extratos purificados ( $1 \mu \mathrm{l} \mathrm{cada})$ foram processados através de cromatógrafo gasoso acoplado a detector de captura de elétrons (GC-ECD) para identificação e quantificação dos inseticidas. Dos 15 inseticidas testados, 46,7\% foram detectados enquanto 53,3\% não foram detectados nas amostras de mel. O heptacloro foi o inseticida mais prevalente com um nível médio de $0,0018 \mathrm{mg} / \mathrm{kg}$ detectado em $80 \%$ das amostras, seguido por $\beta$-HCH com um nível médio de 0,0016 mg / kg detectado em $71,4 \%$ das amostras de mel. Amostras de mel da parede de Acacia modesta foram $100 \%$ positivos para heptacloro com um nível médio de $0,0048 \mathrm{mg} / \mathrm{kg}$ seguido por $\beta$-HCH com um nível médio de 0,003 mg / $\mathrm{kg}$ e frequência de $83,3 \%$. Níveis mínimos dos inseticidas testados foram detectados no mel unifloral de Ziziphus jujuba da usina. Metoxicloro, Endosulfan, Endrin e metabólitos do DDT não foram detectados nas amostras de mel estudadas. Alguns dos inseticidas testados são proibidos no Paquistão, mas ainda são detectados em amostras de mel, indicando seu uso na área de estudo. Os níveis detectados de todos os inseticidas estavam abaixo dos Níveis Máximos de Resíduos (MRLs) e seguros para os consumidores. No entanto, os níveis detectados podem causar mortalidade na fauna de insetos. O uso de inseticidas proibidos é um dos principais fatores responsáveis pelo declínio das populações de importantes insetos polinizadores, incluindo as abelhas.
\end{abstract}

Palavras-chave: inseticidas, abelhas, insetos polinizadores, saúde pública, GC-ECD.

*e-mail: m.attaullah@uom.edu.pk; attaullah.ms@gmail.com

Received: March 28, 2021 - Accepted: May 25, 2021 


\section{Introduction}

Honey is a complex matrix of at least 181 constituents used worldwide for nutritional and therapeutic purposes (Alvarez-Suarez et al., 2010). Honey should be free of chemical contamination for human use but like many other foods, it is prone to environmental contaminants. Determination of insecticide residues in bee products is necessary for ensuring safety to consumers and bee populations (Fernández et al., 2002). Honeybees and their products can be effectively used as bioindicators of environmental pollution from miticides (Fell and Cobb, 2009), trace and heavy metals and metalloids (Zhelyazkova, 2012; Yaqub et al., 2020; Lazarus et al., 2021), polychlorinated biphenyls (Santos et al., 2021), DDT (Cervera-Chiner et al., 2020; Freitas et al., 2021) and various pesticides (Alghamdi et al., 2020; Choi et al., 2020; Bramlitt, 2021; Rodríguez-Martínez et al., 2021). Honeybees fly several kilometers all around from their apiaries and have access to a large area picking pesticides through various pathways like collection of contaminated nectar, pollen and resins (Tosi et al., 2018), through contact with contaminated crops and plants, inhalation from contaminated air, ingestion with polluted water and through direct application of miticides and pesticides (Bogdanov, 2006; Colin et al., 2004).

Pesticides play main role in the decline of honeybee populations at individual as well as colony levels (Potts et al., 2010; Sánchez-Bayo et al., 2016; Tosi et al., 2017; Sánchez-Bayo and Wyckhuys, 2019). Sublethal doses of pesticides in honeybees affect their behavior and immune system (Desneux et al., 2007), reproduction and learning (Wu et al., 2011; Williamson and Wright, 2013), locomotion (Tosi and Nieh, 2017), and homing flight (Tosi et al., 2017).

Use of organochlorine insecticides started in the 1940s and have played a key role in public health and agriculture sector (Ruiz-Toledo et al., 2018). Due to the adverse effects of organochlorine insecticides in humans and other fauna, they were started banning worldwide in the beginning of 1970s including Pakistan, but their residues and impact still prevail due to their persistence and longer half-lives in the environment which range from few days to several years (Faheem et al., 2015; Jayaraj et al., 2016).

Majority of pesticides reported to date from Pakistan in milk, fruits, vegetables, fish meal and cottonseed samples are chlorinated and exceeds the Maximum Residue Level (MRL) (Tariq et al., 2007). Organochlorine insecticides have also been reported in breast milk and human serum samples of cancer patients from Pakistan (Khwaja et al., 2013; Attaullah et al., 2018, 2019). The presence of organochlorine insecticides is a matter of concern for public health and for the populations of insect fauna. The ongoing decline of important insect pollinators particularly honeybees is mainly associated with the indiscriminate use of insecticides. In Pakistan, very little attention is given to the role of insecticides and their impact on the insect pollinators, human health and environmental hazards. There is a dire need to evaluate the residues of various contaminants particularly the commonly used organochlorine insecticides in beehive products to evaluate the risk posed by these chemicals to honeybees and public health.

The present study was conducted to evaluate the levels of fifteen organochlorine insecticides in honey samples of different floral origins at Dir Upper and Dir Lower, Pakistan. This study is the first of its kind in the study area and the detected levels of organochlorine insecticides in honey samples will act as indicator of the illegal use of these banned pesticides in the ambient environment as well as indicator of the level of risk posed by these contaminants to honeybees and public health.

\section{Materials and Methods}

\subsection{Sampling}

Raw honey samples of different floral origins $(n=35)$ were collected during 2017 and 2018 at managed and natural apiaries and local markets of District Dir Upper and Dir Lower, Khyber Pakhtunkhwa province, Pakistan. Common honeybee species found in the study area is Apis mellifera L. The honey samples were classified into six categories based on the floral origin (as shown in Table 1 ). In the present study, fifteen organochlorine insecticides were studied in honey samples which are tabulated (as shown in Table 2).

\subsection{Preparation of standards and stock solutions}

Pesticide standards, organic solvents and chemicals used were of GC grade (Merck, Germany). For stock solutions, $100 \mu \mathrm{g} / \mathrm{mL}$ reference standards were individually prepared in n-hexane in a $100 \mathrm{~mL}$ of volumetric flask. For working solutions, $5 \mathrm{~mL}$ of stock solution was diluted in $50 \mathrm{~mL}$ of n-hexane for the preparation of $10 \mu \mathrm{g} / \mathrm{mL}$ of individual standard solution. Analysis of organochlorine insecticides in honey samples was carried out according to previously described methods by Jimenez et al. (1998), Choudhary and Sharma (2008) and Malhat et al. (2015).

Table 1. Types of honey samples analyzed for organochlorine insecticides.

\begin{tabular}{ccccc}
\hline $\begin{array}{c}\text { Sample } \\
\text { Code }\end{array}$ & $\begin{array}{c}\text { Honey } \\
\text { Type }\end{array}$ & $\begin{array}{c}\text { Scientific } \\
\text { name }\end{array}$ & $\begin{array}{c}\text { Vernacular } \\
\text { name }\end{array}$ & $\mathbf{n}^{*}$ \\
\hline H1-H6 & Unifloral & $\begin{array}{c}\text { Ziziphus } \\
\text { jujuba }\end{array}$ & Bera & 06 \\
H7-H12 & Unifloral & $\begin{array}{c}\text { Acacia } \\
\text { modesta }\end{array}$ & Palosa & 06 \\
H13-H17 & Unifloral & $\begin{array}{c}\text { Acacia } \\
\text { nilotica }\end{array}$ & Kikar & 05 \\
H18-H23 & Unifloral & $\begin{array}{c}\text { Brassica } \\
\text { campestris }\end{array}$ & Sarson & 06 \\
H24-H27 & Unifloral & $\begin{array}{c}\text { Helianthus } \\
\text { annuus }\end{array}$ & Suraj Mukhi & 04 \\
H28-H35 & Multifloral & -- & -- & 08 \\
Total & -- & -- & - & 35 \\
\hline
\end{tabular}

${ }^{*} \mathrm{n}$ : Number of samples. 
Table 2. Detected levels of the fifteen organochlorine insecticides $(\mathrm{mg} / \mathrm{kg})$ in the studied honey samples.

\begin{tabular}{|c|c|c|c|c|c|c|}
\hline Name of insecticides & $\begin{array}{c}\text { Mean } \\
\text { (mg/kg) }\end{array}$ & SD & $\begin{array}{c}\text { Max. } \\
\text { (mg/kg) }\end{array}$ & $\begin{array}{l}\text { Range } \\
\text { (mg/kg) }\end{array}$ & CI (95\%) & $\begin{array}{c}\text { Positive } \\
\text { Percentage }\end{array}$ \\
\hline НCB & 0.0002 & 0.0005 & 0.0031 & 0.0031 & 0.0001 & 51.4 \\
\hline$\alpha-\mathrm{HCH}$ & -- & -- & -- & -- & -- & -- \\
\hline$\beta-\mathrm{HCH}$ & 0.0016 & 0.0017 & 0 & 0.0055 & 0.0005 & 71.4 \\
\hline$\gamma-\mathrm{HCH}$ & -- & -- & -- & -- & -- & -- \\
\hline Heptachlor & 0.0018 & 0.0019 & 0.0067 & 0.0067 & 0.0006 & 80 \\
\hline Aldrin & 0.0004 & 0.0005 & 0.0031 & 0.0031 & 0.0002 & 68.5 \\
\hline Hepta exo-epoxide & 0.0001 & 0.0004 & 0.0021 & 0.0021 & 0.0001 & 25.7 \\
\hline Hepta endo-epoxide & 0.0005 & 0.0019 & 0.0112 & 0.0112 & 0.0006 & 57.1 \\
\hline Dieldrin & 0.00007 & 0.0001 & 0.0011 & 0.0011 & 0.00006 & 28.5 \\
\hline Endrin & -- & -- & -- & -- & -- & -- \\
\hline Endosulfan & -- & -- & -- & -- & -- & -- \\
\hline DDD & -- & -- & -- & -- & -- & -- \\
\hline DDE & -- & -- & -- & -- & -- & -- \\
\hline DDT & -- & -- & -- & -- & -- & -- \\
\hline Methoxychlor & -- & -- & -- & -- & -- & -- \\
\hline
\end{tabular}

Max.: Maximum detected level; --: Not Detected; SD: Standard Deviation; CI: Confidence Interval.

\subsection{Extraction}

Honey sample ( $5 \mathrm{~g}$ each) was mixed with $10 \mathrm{~mL}$ of methanol-distilled water (30:70 v/v) and then homogenized to reduce its viscosity. A mixture of n-hexane and ethyl acetate ( $10 \mathrm{~mL}$ each) at (50:50 v/v) was added and agitated for 20 minutes followed by centrifugation at $3000 \mathrm{rpm}$ for 10 minutes. The supernatant was collected in a separator flask and the residues were re-extracted twice with $10 \mathrm{~mL}$ of ethyl acetate. Rotary evaporator was used for the evaporation of solvent till dryness at $65{ }^{\circ} \mathrm{C}$. The residues were dissolved in $5 \mathrm{~mL}$ of ethyl acetate.

\subsection{Clean-up}

The $5 \mathrm{~mL}$ extract of each sample was purified by passing through a column containing $0.5 \mathrm{~g}$ silica, $1 \mathrm{~g}$ anhydrous sodium sulphate and $2 \mathrm{~g}$ of activated Florisil. The column was pre-washed with n-hexane $(10 \mathrm{~mL})$ and then $5 \mathrm{~mL}$ extract of each sample was passed one by one for purification from impurities. Each time the columns were thoroughly flushed with n-hexane $(20 \mathrm{~mL})$ before running the new sample. The eluate of each sample was concentrated to dryness in centrifuge tubes and each was re-dissolved in ethyl acetate $(1 \mathrm{~mL})$ and stored at $-20{ }^{\circ} \mathrm{C}$.

\subsection{Gas chromatographic analysis}

The extracted eluate ( $1 \mu \mathrm{L}$ each) was analyzed through Claurus Gas Chromatograph coupled with 63Ni Electron Capture Detector at Center for Environmental Studies, Pakistan Council for Scientific and Industrial Research Laboratories Complex, Karachi. DB-5 silica capillary column $(30 \mathrm{~m} \times 0.25 \mathrm{~mm} \times 0.25 \mu \mathrm{m})$ was used with $1 \mu \mathrm{L}$ of sample volume in split-less mode. Temperature was programmed as: Detector $\left(280{ }^{\circ} \mathrm{C}\right)$; Injector port $\left(220^{\circ} \mathrm{C}\right)$ at the rate of $10^{\circ} \mathrm{C} / \mathrm{min}, 150^{\circ} \mathrm{C}$ held for $1 \mathrm{~min}$ to $210^{\circ} \mathrm{C}$ held for $1 \mathrm{~min}$ with final rate of $3^{\circ} \mathrm{C}$ per min to $250{ }^{\circ} \mathrm{C}$ and held for 3 minutes. Helium was used as the carrier gas while make-up gas was Nitrogen at $120 \mathrm{kPa}$. Chromatograms of the samples were compared with the standard chromatograms for identification and quantification of the individual analytes. Recovery and sensitivity experiments were conducted by adding known volumes of the tested pesticides in triplicate at various fortification levels. Blank samples were also processed for finding out the differences, if any. The average recovery percentages were determined for the fortified samples. Limits of detection (LODs) and limits of quantification (LOQs) were determined as the concentration of pesticide producing a peak with signal to noise ratio $(\mathrm{S} / \mathrm{N})$ of $3 / 1$ and $10 / 1$ respectively.

\subsection{Data analysis}

Data was calculated by using Microsoft Excel (Version 2016) and presented as percentage, mean, standard deviation, range and confidence intervals of the organochlorine insecticides detected in honey samples of different floral origins.

\section{Results}

Honey samples of different floral origins locally available in the study area were evaluated for the presence of fifteen organochlorine pesticides including $\mathrm{HCB}, \alpha-\mathrm{HCH}, \beta-\mathrm{HCH}$, $\gamma$-HCH, Heptachlor, Aldrin, Heptachlor exo-epoxide, Heptachlor endo-epoxide, Dieldrin, Endrin, Endosulfan, DDD, DDE, DDT and Methoxychlor. The samples were found positive for $46.7 \%$ of the tested pesticides including $\mathrm{HCB}, \beta-\mathrm{HCH}$, Heptachlor, Aldrin, Heptachlor exo-epoxide, Heptachlor endo-epoxide and Dieldrin. Remaining 53.3\% 
of the tested organochlorine insecticides including $\alpha-\mathrm{HCH}, \gamma-\mathrm{HCH}$, Endrin, Endosulfan, DDD, DDE, DDT and Methoxychlor were not detected in the honey samples (as shown in Table 2, see Figure 1).

The most prevalent organochlorine insecticide was Heptachlor with a mean detected level of $0.0018 \mathrm{mg} / \mathrm{kg}$, detected in $80 \%$ of the samples followed by $\beta-\mathrm{HCH}(0.0016 \mathrm{mg} / \mathrm{kg})$, detected in $71.4 \%$ of the honey samples (as shown in Table 2 ).

Heptachlor was detected in $100 \%$ of the honey samples from Acacia modesta, Brassica campestris and multifloral honey (as shown in Tables 3, 4 and 5; see Figure 2). Honey from Acacia modesta was found with highest detected mean level of heptachlor $(0.0048 \mathrm{mg} / \mathrm{kg})$ detected in $100 \%$ of the samples followed by $\beta-\mathrm{HCH}(0.003 \mathrm{mg} / \mathrm{kg})$ detected in $83.3 \%$ of the samples (as shown in Table 3; see Figure 1 and 2).

The least contaminated honey with minimum detected levels of organochlorine insecticides was Ziziphus jujuba honey with a mean level of $\beta-\mathrm{HCH}$ of $0.0003 \mathrm{mg} / \mathrm{kg}$, detected in $66.6 \%$ of the samples followed by Heptachlor $(0.0003 \mathrm{mg} / \mathrm{kg}$ ) detected in $50 \%$ of the samples (as shown in Table 6; see Figure 1 and 2).

Honey from Acacia nilotica, Brassica campestris, Helianthus annuus and multifloral honey was found with moderate levels of the studied organochlorine insecticides (as shown in Table 4, 5, 7 and 8; see Figure 1 and 2).

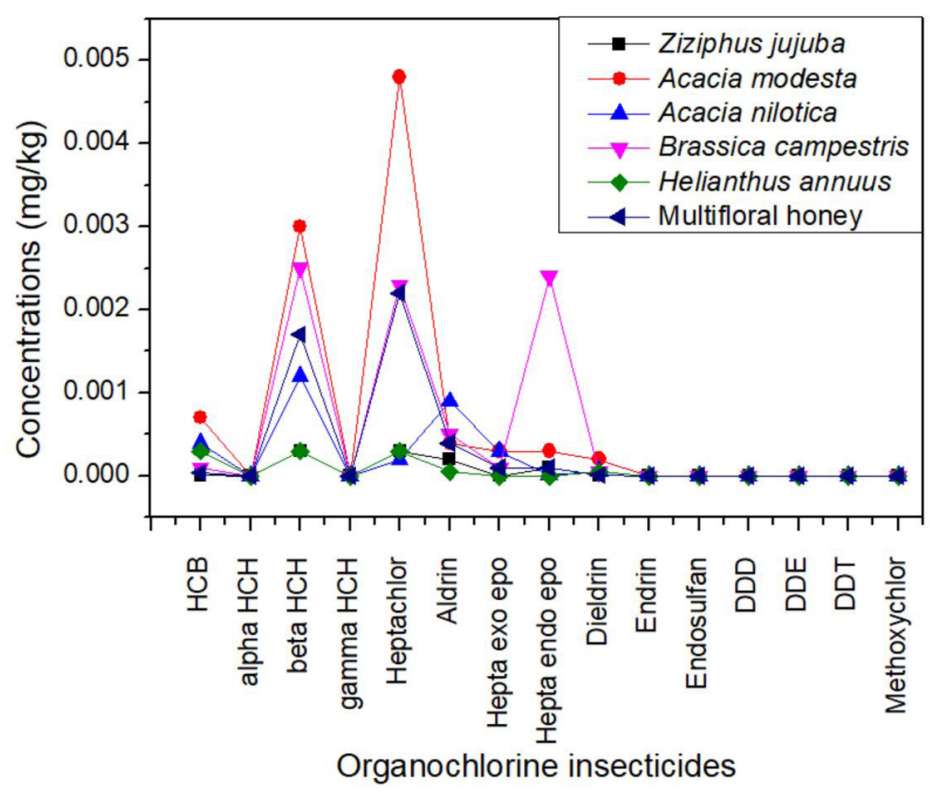

Figure 1. Mean values of organochlorine insecticides in honey samples of different floral origins.

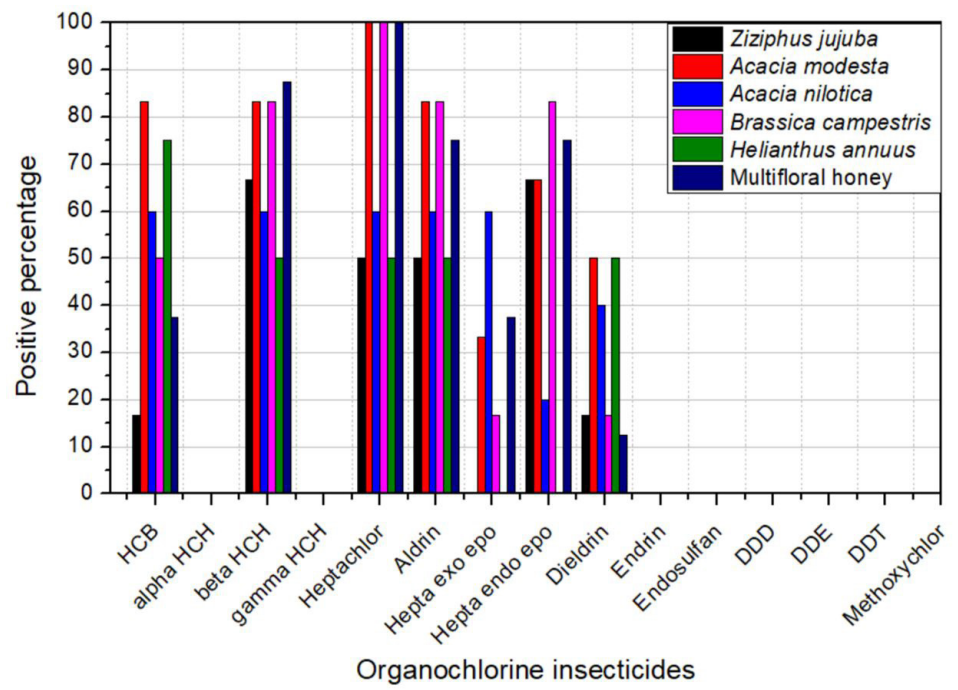

Figure 2. Positive percentage of organochlorine insecticides in honey samples of different floral origins. 
Table 3. Levels of the detected organochlorine insecticides in honey from Acacia modesta.

\begin{tabular}{cllcccc}
\hline $\begin{array}{c}\text { Name of } \\
\text { insecticide }\end{array}$ & $\begin{array}{c}\text { Mean } \\
(\mathbf{m g} / \mathbf{k g})\end{array}$ & SD & $\begin{array}{c}\text { Max. } \\
(\mathbf{m g} / \mathbf{k g})\end{array}$ & $\begin{array}{c}\text { Range } \\
(\mathbf{m g} / \mathbf{k g})\end{array}$ & CI (95\%) & $\begin{array}{c}\text { Positive } \\
\text { Percentage }\end{array}$ \\
\hline HCB & 0.0007 & 0.001 & 0.0031 & 0.0031 & 0.001 & 83.3 \\
$\begin{array}{l}\beta-\mathrm{HCH} \\
\text { Heptachlor }\end{array}$ & 0.003 & 0.001 & 0.0055 & 0.0055 & 0.002 & 83.3 \\
$\quad$ Aldrin & 0.0048 & 0.001 & 0.0067 & 0.0032 & 0.001 & 100 \\
$\begin{array}{c}\text { Hepta exo } \\
\text { epoxide }\end{array}$ & 0.0003 & 0.0002 & 0.0008 & 0.0008 & 0.0003 & 83.3 \\
$\begin{array}{c}\text { Hepta endo } \\
\text { epoxide }\end{array}$ & 0.0003 & 0.0008 & 0.0021 & 0.0021 & 0.0008 & 33.3 \\
Dieldrin & 0.0002 & 0.0002 & 0.0007 & 0.0007 & 0.0002 & 66.6 \\
\hline
\end{tabular}

Table 4. Levels of the detected organochlorine insecticides in honey from Brassica campestris.

\begin{tabular}{ccccccc}
\hline $\begin{array}{c}\text { Name of } \\
\text { insecticide }\end{array}$ & $\begin{array}{c}\text { Mean } \\
(\mathbf{m g} / \mathbf{k g})\end{array}$ & SD & $\begin{array}{c}\text { Max. } \\
(\mathbf{m g} / \mathbf{k g})\end{array}$ & $\begin{array}{c}\text { Range } \\
(\mathbf{m g} / \mathbf{k g})\end{array}$ & CI (95\%) & $\begin{array}{c}\text { Positive } \\
\text { Percentage }\end{array}$ \\
\hline HCB & 0.0001 & 0.0002 & 0.0004 & 0.0004 & 0.0002 & 50 \\
$\begin{array}{c}\beta-\mathrm{HCH} \\
\text { Heptachlor }\end{array}$ & 0.0025 & 0.002 & 0.0047 & 0.0047 & 0.0021 & 83.3 \\
Aldrin & 0.0023 & 0.0016 & 0.0044 & 0.0037 & 0.0017 & 100 \\
$\begin{array}{c}\text { Hepta exo } \\
\text { epoxide }\end{array}$ & 0.0005 & 0.0003 & 0.0009 & 0.0009 & 0.0003 & 83.3 \\
$\begin{array}{c}\text { Hepta endo } \\
\text { epoxide }\end{array}$ & 0.0001 & 0.0003 & 0.0007 & 0.0007 & 0.0003 & 16.6 \\
Dieldrin & 0.0024 & 0.0044 & 0.0112 & 0.0112 & 0.0046 & 83.3 \\
\hline
\end{tabular}

Table 5. Levels of the detected organochlorine insecticides in multifloral honey.

\begin{tabular}{clllllc}
\hline $\begin{array}{c}\text { Name of } \\
\text { insecticide }\end{array}$ & $\begin{array}{c}\text { Mean } \\
(\mathbf{m g} / \mathbf{k g})\end{array}$ & SD & $\begin{array}{c}\text { Max. } \\
(\mathbf{m g} / \mathbf{k g})\end{array}$ & $\begin{array}{c}\text { Range } \\
(\mathbf{m g} / \mathbf{k g})\end{array}$ & CI (95\%) & $\begin{array}{c}\text { Positive } \\
\text { Percentage }\end{array}$ \\
\hline HCB & 0.00004 & 0.00005 & 0.0001 & 0.0001 & 0.00004 & 37.5 \\
$\begin{array}{l}\beta-\mathrm{HCH} \\
\text { Heptachlor }\end{array}$ & 0.0017 & 0.0015 & 0.0038 & 0.0038 & 0.0013 & 87.5 \\
$\quad 0.0022$ & 0.0014 & 0.0044 & 0.0039 & 0.0012 & 100 \\
$\begin{array}{c}\text { Aldrin } \\
\text { Hepta exo } \\
\text { epoxide }\end{array}$ & 0.0004 & 0.0003 & 0.0009 & 0.0009 & 0.0003 & 75 \\
$\begin{array}{c}\text { Hepta endo } \\
\text { epoxide }\end{array}$ & 0.0001 & 0.0002 & 0.0007 & 0.0007 & 0.0002 & 37.5 \\
Dieldrin & 0.0001 & 0.00009 & 0.0002 & 0.0002 & 0.00007 & 75 \\
\hline
\end{tabular}

Table 6. Levels of the detected organochlorine insecticides in honey from Ziziphus jujuba.

\begin{tabular}{cllcccc}
\hline $\begin{array}{c}\text { Name of } \\
\text { insecticide }\end{array}$ & $\begin{array}{c}\text { Mean } \\
(\mathbf{m g} / \mathbf{k g})\end{array}$ & SD & $\begin{array}{c}\text { Max. } \\
(\mathbf{m g} / \mathbf{k g})\end{array}$ & $\begin{array}{c}\text { Range } \\
(\mathbf{m g} / \mathbf{k g})\end{array}$ & CI (95\%) & $\begin{array}{c}\text { Positive } \\
\text { Percentage }\end{array}$ \\
\hline HCB & 0.00001 & 0.00004 & 0.0001 & 0.0001 & 0.00004 & 16.6 \\
$\beta$-HCH & 0.0003 & 0.0004 & 0.0011 & 0.0011 & 0.0004 & 66.6 \\
Heptachlor & 0.0003 & 0.0006 & 0.0015 & 0.0015 & 0.0006 & 50 \\
Aldrin & 0.0002 & 0.0003 & 0.0008 & 0.0008 & 0.0003 & 50 \\
$\begin{array}{c}\text { Hepta endo } \\
\text { epoxide }\end{array}$ & 0.0001 & 0.00008 & 0.0002 & 0.0002 & 0.00009 & 66.6 \\
Dieldrin & 0.00001 & 0.00004 & 0.0001 & 0.0001 & 0.00004 & 16.6 \\
\hline
\end{tabular}


Table 7. Levels of the detected organochlorine insecticides in honey from Acacia nilotica.

\begin{tabular}{clllllc}
\hline $\begin{array}{c}\text { Name of } \\
\text { insecticide }\end{array}$ & $\begin{array}{c}\text { Mean } \\
(\mathbf{m g} / \mathbf{k g})\end{array}$ & SD & $\begin{array}{c}\text { Max. } \\
(\mathbf{m g} / \mathbf{k g})\end{array}$ & $\begin{array}{c}\text { Range } \\
(\mathbf{m g} / \mathbf{k g})\end{array}$ & CI (95\%) & $\begin{array}{c}\text { Positive } \\
\text { Percentage }\end{array}$ \\
\hline HCB & 0.0004 & 0.0005 & 0.0012 & 0.0012 & 0.0006 & 60 \\
$\begin{array}{l}\beta \text {-HCH } \\
\text { Heptachlor }\end{array}$ & 0.0012 & 0.0016 & 0.0038 & 0.0038 & 0.002 & 60 \\
Aldrin & 0.0002 & 0.0003 & 0.0007 & 0.0007 & 0.0004 & 60 \\
$\begin{array}{c}\text { Hepta exo } \\
\text { epoxide }\end{array}$ & 0.0009 & 0.001 & 0.0031 & 0.0031 & 0.001 & 60 \\
$\begin{array}{c}\text { Hepta endo } \\
\text { epoxide }\end{array}$ & 0.00002 & 0.0004 & 0.0009 & 0.0009 & 0.0005 & 60 \\
Dieldrin & 0.00006 & 0.00008 & 0.0002 & 0.0002 & 0.00005 & 20 \\
\hline
\end{tabular}

Table 8. Levels of the detected organochlorine insecticides in honey from Helianthus annuus.

\begin{tabular}{clllllc}
\hline $\begin{array}{c}\text { Name of } \\
\text { insecticide }\end{array}$ & $\begin{array}{c}\text { Mean } \\
(\mathbf{m g} / \mathbf{k g})\end{array}$ & SD & $\begin{array}{c}\text { Max. } \\
(\mathbf{m g} / \mathbf{k g})\end{array}$ & $\begin{array}{c}\text { Range } \\
(\mathbf{m g} / \mathbf{k g})\end{array}$ & CI (95\%) & $\begin{array}{c}\text { Positive } \\
\text { Percentage }\end{array}$ \\
\hline HCB & 0.0003 & 0.0005 & 0.0011 & 0.0011 & 0.0008 & 75 \\
$\beta$-HCH & 0.0003 & 0.0003 & 0.0007 & 0.0007 & 0.0005 & 50 \\
Heptachlor & 0.0003 & 0.0004 & 0.0008 & 0.0008 & 0.0006 & 50 \\
Aldrin & 0.00005 & 0.00006 & 0.0001 & 0.0001 & 0.00009 & 50 \\
Dieldrin & 0.00005 & 0.00006 & 0.0001 & 0.0001 & 0.00009 & 50 \\
\hline
\end{tabular}

\section{Discussion}

Fifteen organochlorine pesticides were studied in honey samples of different floral origins. The detected levels indicate the use of these pesticides in the ambient environment. If residues of these persistent pesticides are higher than the Maximum Residue Levels, then they may pose a risk to public health. Honeybees and other insect pollinators can be affected even in very low levels. MRL for most of the organochlorine insecticides in honey samples is $0.01 \mathrm{mg} / \mathrm{kg}$ while MRL for DDT and its metabolites is $0.05 \mathrm{mg} / \mathrm{kg}$ (Tette et al., 2016; European Union, 2006). Levels of the fifteen organochlorine insecticides in all honey samples were below the MRL and may not be harmful to consumers but may severely affect the health and physiology of honeybees. Pesticide residues in honey samples reported from Spain (García-Chao et al., 2010) and Turkey (Yavuz et al., 2010), exceeded the MRL and were higher than those obtained in the present study. Organochlorine insecticide with highest frequency of detection were mostly those also having higher mean levels (as shown in Table 2; see Figure 1). Due to the persistence of organochlorine insecticides and bioaccumulation in tissues, there is a possibility that they can build up to deleterious levels thereby causing toxicity to bees. Fipronil a chlorinated pesticide in sub-lethal doses has been confirmed causing severe damage to honeybee colonies (Aliouane et al., 2009). The sublethal levels of the detected pesticides in the present study may pose risk to honeybees and other insect pollinators.

Some of the recent studies from Pakistan have reported organochlorine insecticides in a variety of samples (Randhawa et al., 2016; Attaullah et al., 2018). This indicate that these chemicals are still prevalent in the environment and may pose health hazards to public health and risk to honeybee populations. Concentrations of HCB, Heptachlor and Aldrin detected in the present study were lower than reported in honey from Portugal (Blasco et al., 2004), Turkey (Erdoğrul, 2007) and Ghana (Darko et al., 2017). Mean level of $\beta$-HCH was $0.0016 \mathrm{mg} / \mathrm{kg}$ and detected in $71.4 \%$ of the honey samples (as shown in Table 2 ). It is in conformance with a previous report on $\beta-\mathrm{HCH}$ in honey (Wang et al., 2010). Endosulfan was detected in none of the tested honey samples although it has been recently reported in honey samples from other parts of Pakistan with levels exceeding MRL(Farooqi et al., 2017). In Romania, levels of HCHs and DDTs were detected in 50\% and 25\% of the honey samples respectively (Antonescu and Mateescu, 2001). $\beta$-HCH was the second most detected organochlorine insecticide in the present study while residues of DDTs were not detected in any of the honey samples.

The honey samples were found positive for at least some of the organochlorine insecticides acting as indicator of the illegal use of these banned insecticides in the ambient environment. The levels of organochlorine insecticides were below MRLs and declared as safe for public health. However, the detected levels are enough to cause harm to honeybees' health. This may be one of the important factors responsible for the declining populations of honeybees and other insect pollinators in the study area. Honey with high contamination of organochlorine insecticides was from Acacia modesta followed by Brassica campestris, while the least organochlorine insecticide contaminated honey was from Ziziphus jujuba. Further studies are recommended to study a wider spectrum of insecticides not only in honey 
samples but also in pollens, propolis, royal jelly and bees wax. Ecofriendly pest control measures and Integrated Pest Management (IPM) techniques should be promoted as a better alternative to chemical control for the conservation of biodiversity including honeybees and for ensuring public health safety.

\section{Acknowledgements}

We acknowledge the financial support provided by the Higher Education Commission of Pakistan for funding this study.

\section{References}

ALGHAMDI, B.A., ALSHUMRANI, E.S., SAEED, M.S.B., RAWAS, G.M., ALHARTHI, N.T., BAESHEN, M.N., HELMI, N.M., ALAM, M.Z. and SUHAIL, M., 2020. Analysis of sugar composition and pesticides using HPLC and GC-MS techniques in honey samples collected from Saudi Arabian markets. Saudi Journal of Biological Sciences, vol. 27, no. 12, pp. 3720-3726. http://dx.doi.org/10.1016/j. sjbs.2020.08.018. PMid:33304183.

ALIOUANE, Y., EL HASSANI, A.K., GARY, V., ARMENGAUD, C., LAMBIN, M. and GAUTHIER, M., 2009. Subchronic exposure of honeybees to sublethal doses of pesticides: effects on behavior. Environmental Toxicology and Chemistry: An International Journal, vol. 28, no. 1, pp. 113-122. http://dx.doi.org/10.1897/08-110.1. PMid: 18700810.

ALVAREZ-SUAREZ, J.M., TULIPANI, S., ROMANDINI, S., BERTOLI, E. and BATTINO, M., 2010. Contribution of honey in nutrition and human health: a review. Mediterranean Journal of Nutrition and Metabolism, vol. 3, no. 1, pp. 15-23. http://dx.doi.org/10.1007/ s12349-009-0051-6.

ANTONESCU, C. and MATEESCU, C., 2001. Environmental pollution and its effects on honey quality. Romanian Biotechnological Letters, vol. 6, pp. 371-380.

ATTAULLAH, M., YOUSUF, M.J., AMIN, M., BUNERI, I.D., RAHIM, A., ANJUM, S. and ILAHI, I., 2019. Endosulfan concentrations in association with serum biochemical parameters and risk of cancer. Applied Ecology and Environmental Research, vol. 17, no. 2, pp. 5235-5244. http://dx.doi.org/10.15666/aeer/1702_52355244.

ATTAULLAH, M., YOUSUF, M.J., SHAUKAT, S., ANJUM, S.I., ANSARI, M.J., BUNERI, I.D., TAHIR, M., AMIN, M., AHMAD, N. and KHAN, S.U., 2018. Serum organochlorine pesticides residues and risk of cancer: a case-control study. Saudi Journal of Biological Sciences, vol. 25, no. 7, pp. 1284-1290. http://dx.doi.org/10.1016/j. sjbs.2017.10.023. PMid:30505171.

BLASCO, C., LINO, C.M., PICÓ, Y., PENA, A., FONT, G. and SILVEIRA, M.I.N., 2004. Determination of organochlorine pesticide residues in honey from the central zone of Portugal and the Valencian community of Spain. Journal of Chromatography. A, vol. 1049, no. 1-2, pp. 155-160. http://dx.doi.org/10.1016/j. chroma.2004.07.049. PMid:15499928.

BOGDANOV, S., 2006. Contaminants of bee products. Apidologie, vol. 37, no. 1, pp. 1-18. http://dx.doi.org/10.1051/apido:2005043.

BRAMLITT, M., 2021 [viewed 28 March 2021]. Initial investigation of select pesticides present in wildflower honey using headspace solid-phase microextraction coupled with gas chromatographymass spectrometry [online]. Conway: Coastal Carolina University. Available from: https://digitalcommons.coastal.edu/ugrc/2021/ fullconference/ 101
CERVERA-CHINER, L., MARCH, C., ARNAU, A., JIMÉNEZ, Y. and MONTOYA, Á., 2020. Detection of DDT and carbaryl pesticides in honey by means of immunosensors based on high fundamental frequency quartz crystal microbalance (HFF-QCM). Journal of the Science of Food and Agriculture, vol. 100, no. 6, pp. 24682472. http://dx.doi.org/10.1002/jsfa.10267. PMid:31965575.

CHOI, Y.C., NG, T.T., HU, B., LI, R. and YAO, Z.P., 2020. Rapid detection of pesticides in honey by solid-phase micro-extraction coupled with electrospray ionization mass spectrometry. Journal of Mass Spectrometry, vol. 55, no. 2, pp. e4380. http://dx.doi. org/10.1002/jms.4380. PMid:31183930.

CHOUDHARY, A. and SHARMA, D.C., 2008. Pesticide residues in honey samples from Himachal Pradesh (India). Bulletin of Environmental Contamination and Toxicology, vol. 80, no. 5, pp. 417-422. http://dx.doi.org/10.1007/s00128-008-9426-5. PMid: 18506381.

COLIN, M.E., BONMATIN, J.M., MOINEAU, I., GAIMON, C., BRUN, S. and VERMANDERE, J.P., 2004. A method to quantify and analyze the foraging activity of honeybees: relevance to the sublethal effects induced by systemic insecticides. Archives of Environmental Contamination and Toxicology, vol. 47, no. 3, pp. 387-395. http://dx.doi.org/10.1007/s00244-004-3052-y. PMid: 15386133.

DARKO, G., ADDAI TABI, J., ADJALOO, M.K. and BORQUAYE, L.S., 2017. Pesticide residues in honey from the major honey producing forest belts in Ghana. Journal of Environmental and Public Health, vol. 2017, pp. 7957431. http://dx.doi.org/10.1155/2017/7957431. PMid:28951746.

DESNEUX, N., DECOURTYE, A. and DELPUECH, J.M., 2007. The sublethal effects of pesticides on beneficial arthropods. Annual Review of Entomology, vol. 52, no. 1, pp. 81-106. http://dx.doi. org/10.1146/annurev.ento.52.110405.091440. PMid:16842032.

ERDOĞRUL, Ö., 2007. Levels of selected pesticides in honey samples from Kahramanmaraş, Turkey. Food Control, vol. 18, no. 7, pp. 866-871. http://dx.doi.org/10.1016/j.foodcont.2006.05.001.

EUROPEAN UNION, 2006. Commission amending Regulation (EC) No 396/2005. Official Journal of the European Union, Brussels, 16 mar.

FAHEEM, N., SAJJAD, A., MEHMOOD, Z., IQBAL, F., MAHMOOD, Q., MUNSIF, S. and WASEEM, A., 2015. The pesticide exposure through fruits and meat in Pakistan. Fresenius Environmental Bulletin, vol. 24, no. 12, pp. 4555-4566.

FAROOQI, M.A., HASAN, M., AKHTAR, S., ARSHAD, M., ASLAM, M.N. and RAFAY, M., 2017. Detection of insecticide residues in honey of Apis dorsata F. from Southern Punjab, Pakistan. Pakistan Journal of Zoology, vol. 49, no. 5, pp. 1761-1766. http://dx.doi. org/10.17582/journal.pjz/2017.49.5.1761.1766.

FELL, R.D. and СОВB, J.M., 2009. Miticide residues in Virginia honeys. Bulletin of Environmental Contamination and Toxicology, vol. 83, no. 6, pp. 822-827. http://dx.doi.org/10.1007/s00128009-9806-5. PMid:19565169.

FERNÁNDEZ, M., PICÓ, Y. and MANES, J., 2002. Analytical methods for pesticide residue determination in bee products. Journal of Food Protection, vol. 65, no. 9, pp. 1502-1511. http://dx.doi. org/10.4315/0362-028X-65.9.1502. PMid:12233867.

FREITAS, L.V.P., ALVES, L.M.G., SICUPIRA, L.C., PINHO, G.P. and SILVÉRIO, F.O., 2021. Determination of DDT in honey samples by liquid-liquid extraction with low-temperature purification (LLE-LTP) combined to HPLC-DAD. Analytical Methods, vol. 13, no. 16, pp. 1955-1964. http://dx.doi.org/10.1039/D1AY00264C. PMid:33913942.

GARCÍA-CHAO, M., AGRUÑA, M.J., FLORES CALVETE, G., SAKKAS, V., LLOMPART, M. and DAGNAC, T., 2010. Validation of an 
offline solid phase extraction liquid chromatography-tandem mass spectrometry method for the determination of systemic insecticide residues in honey and pollen samples collected in apiaries from NW Spain. Analytica Chimica Acta, vol. 672, no. 1-2, pp. 107-113. http://dx.doi.org/10.1016/j.aca.2010.03.011. PMid:20579498.

JAYARAJ, R., MEGHA, P. and SREEDEV, P., 2016. Organochlorine pesticides, their toxic effects on living organisms and their fate in the environment. Interdisciplinary Toxicology, vol. 9, no. 3-4, pp. 90-100. http://dx.doi.org/10.1515/intox-2016-0012. PMid:28652852.

JIMÉNEZ, J.J., BERNAL, J.L., DEL NOZAL, M.J., TORIBIO, L. and MARTÍN, M.T., 1998. Gas chromatography with electron-capture and nitrogen-phosphorus detection in the analysis of pesticides in honey after elution from a Florisil column: influence of the honey matrix on the quantitative results. Journal of Chromatography. A, vol. 823, no. 1-2, pp. 381-387. http://dx.doi.org/10.1016/ S0021-9673(98)00292-1. PMid:9818415.

KHWAJA, S., MUSHTAQ, R., MUSHTAQ R., YOUSUF, M., ATTAULLAH, M., TABBASSUM, F. and FAIZ, R., 2013. Monitoring of biochemical effects of organochlorine pesticides on human health. Health, vol. 5, no. 8, pp. 1342-1350. http://dx.doi.org/10.4236/ health.2013.58182.

LAZARUS, M., LOVAKOVIĆ, B.T., ORCT, T., SEKOVANIĆ, A., BILANDŽIĆ, N., ĐOKIĆ, M., KOLANOVIĆ, B.S., VARENINA, I., JURIČ, A., LUGOMER, M.D. and BUBALO, D., 2021. Difference in pesticides, trace metal (loid) $s$ and drug residues between certified organic and conventional honeys from Croatia. Chemosphere, vol. 266, pp. 128954. http://dx.doi.org/10.1016/j. chemosphere.2020.128954. PMid:33250227.

MALHAT, F.M., HAGGAG, M.N., LOUTFY, N.M., OSMAN, M.A. and AHMED, M.T., 2015. Residues of organochlorine and synthetic pyrethroid pesticides in honey, an indicator of ambient environment, a pilot study. Chemosphere, vol. 120, pp. 457461. http://dx.doi.org/10.1016/j.chemosphere.2014.08.032. PMid:25243805.

POTTS, S.G., BIESMEIJER, J.C., KREMEN, C., NEUMANN, P., SCHWEIGER, O. and KUNIN, W.E., 2010. Global pollinator declines: trends, impacts and drivers. Trends in Ecology $\mathcal{E}$ Evolution, vol. 25, no. 6, pp. 345-353. http://dx.doi.org/10.1016/j. tree.2010.01.007. PMid:20188434.

RANDHAWA, M.A., ABID, Q.U.Z., ANJUM, F.M., CHAUDHARY, A.S., SAJID, M.W. and KHALIL, A.A., 2016. Organo-chlorine pesticide residues in okra and brinjal collected from peri-urban areas of big cities of Punjab Pakistan. Pakistan Journal of Agricultural Sciences, vol. 53, no. 2, pp. 425. http://dx.doi.org/10.21162/ PAKJAS/16.1895.

RODRÍGUEZ-MARTÍNEZ, R., GASPAR-RAMÍREZ, O., VÉLIZ-DERAS, F., MORENO-RESÉNDEZ, A., REYES-CARRILLO, J. and VARGASVALERO, A., 2021. Pesticides residues in honey and wax from bee colonies in La Comarca Lagunera. Abanico Veterinario, vol. 10, no. 1, pp. 1-16.

RUIZ-TOLEDO, J., VANDAME, R., CASTRO-CHAN, R.A., PENILLANAVARRO, R.P., GÓMEZ, J. and SÁNCHEZ, D., 2018. Organochlorine pesticides in honey and pollen samples from managed colonies of the honeybee Apis mellifera Linnaeus and the stingless bee Scaptotrigona mexicana Guérin from Southern, Mexico. Insects, vol. 9, no. 2, pp. 54. http://dx.doi.org/10.3390/insects9020054. PMid:29748485.

SÁNCHEZ-BAYO, F. and WYCKHUYS, K.A., 2019. Worldwide decline of the entomofauna: a review of its drivers. Biological
Conservation, vol. 232, pp. 8-27. http://dx.doi.org/10.1016/j. biocon.2019.01.020.

SÁNCHEZ-BAYO, F., GOULSON, D., PENNACCHIO, F., NAZZI, F., GOKA, K. and DESNEUX, N., 2016. Are bee diseases linked to pesticides? A brief review. Environment International, vol. 89-90, pp. 7-11. http://dx.doi.org/10.1016/j.envint.2016.01.009. PMid:26826357.

SANTOS, M., VARELI, C.S., JANISCH, B., PIZZUTTI, I.R., FORTES, J., SAUTTER, C.K. and COSTABEBER, I.H., 2021. Contamination of polychlorinated biphenyls in honey from the Brazilian state of Rio Grande do Sul. Food Additives E Contaminants: Part A, vol. 38, no. 3, pp. 452-463. http://dx.doi.org/10.1080/194400 49.2020.1865578. PMid:33459200.

TARIQ M.I., AFZAL, S., HUSSAIN, I. and SULTANA, N., 2007. Pesticides exposure in Pakistan: a review. Environment International, vol. 33, no. 8, pp. 1107-1122. http://dx.doi.org/10.1016/j. envint.2007.07.012. PMid:17765971.

TETTE, P.A.S., GUIDI, L.R., ABREU GLÓRIA, M.B. and FERNANDES, C., 2016. Pesticides in honey: a review on chromatographic analytical methods. Talanta, vol. 149, pp. 124-141. http://dx.doi. org/10.1016/j.talanta.2015.11.045. PMid:26717823.

TOSI, S. and NIEH, J.C., 2017. A common neonicotinoid pesticide, thiamethoxam, alters honeybee activity, motor functions, and movement to light. Scientific Reports, vol. 7, no. 1, pp. 15132. http://dx.doi.org/10.1038/s41598-017-15308-6.

TOSI, S., BURGIO, G. and NIEH, J.C., 2017. A common neonicotinoid pesticide, thiamethoxam, impairs honeybee flight ability. Scientific Reports, vol. 7, no. 1, pp. 1-8.

TOSI, S., COSTA, C., VESCO, U., QUAGLIA, G. and GUIDO, G., 2018. A 3-year survey of Italian honeybee-collected pollen reveals widespread contamination by agricultural pesticides. The Science of the Total Environment, vol. 615, pp. 208-218. http:// dx.doi.org/10.1016/j.scitotenv.2017.09.226. PMid:28968582.

WANG, J., KLIKS, M.M., JUN, S. and LI, Q.X., 2010. Residues of organochlorine pesticides in honeys from different geographic regions. Food Research International, vol. 43, no. 9, pp. 23292334. http://dx.doi.org/10.1016/j.foodres.2010.08.006.

WILLIAMSON, S.M. and WRIGHT, G.A., 2013. Exposure to multiple cholinergic pesticides impairs olfactory learning and memory in honeybees. The Journal of Experimental Biology, vol. 216, no. 10, pp. 1799-1807. http://dx.doi.org/10.1242/jeb.083931. PMid:23393272.

WU, J.Y., ANELLI, C.M. and SHEPPARD, W.S., 2011. Sub-lethal effects of pesticide residues in brood comb on worker honeybee (Apis mellifera) development and longevity. PLoS One, vol. 6, no. 2, pp. e14720. http://dx.doi.org/10.1371/journal.pone.0014720. PMid:21373182.

YAQUB, G., KHALID, M., IKRAM, A. and SOHAIL, A., 2020. Monitoring and risk assessment due to presence of metals and pesticides residues in honey samples from the major honey producing forest belts and different brands. Food Science and Technology, vol. 40, suppl. 1, pp. 331-335. http://dx.doi.org/10.1590/fst.01919.

YAVUZ, H., GULER, G.O., AKTUMSEK, A., CAKMAK, Y.S. and OZPARLAK, H., 2010. Determination of some organochlorine pesticide residues in honeys from Konya, Turkey. Environmental Monitoring and Assessment, vol. 168, no. 1-4, pp. 277-283. http://dx.doi. org/10.1007/s10661-009-1111-6. PMid:19685151.

ZHELYAZKOVA, I., 2012. Honeybees-bioindicators for environmental quality. Bulgarian Journal of Agricultural Science, vol. 18, no. 3, pp. 435-442. 